Article

\title{
Kingianic Acids A-G, Endiandric Acid Analogues from Endiandra kingiana
}

Mohamad Nurul Azmi ${ }^{1, \dagger}$, Charlotte Gény ${ }^{2, \dagger}$, Aurélie Leverrier ${ }^{2}$, Marc Litaudon ${ }^{2, *}$, Vincent Dumontet ${ }^{2}$, Nicolas Birlirakis ${ }^{2}$, Françoise Guéritte ${ }^{2}$, Kok Hoong Leong ${ }^{3}$, Siti Nadiah Abd. Halim ${ }^{1}$, Khalit Mohamad ${ }^{3}$ and Khalijah Awang ${ }^{1, *}$

1 Department of Chemistry, Faculty of Science, University Malaya, Kuala Lumpur 50603, Malaysia; E-Mails: libra_mine85@yahoo.co.uk (M.N.A.); nadiahhalim@um.edu.my (S.N.A.H.)

2 Centre de Recherche de Gif, Institut de Chimie des Substances Naturelles (ICSN), CNRS, Labex LERMIT, Gif-sur-Yvette Cedex 91198, France; E-Mails: charlotte.geny@cnrs.fr (C.G.); aurelie.leverrier@gmail.com (A.L.); vincent.dumontet@cnrs.fr (V.D.); nicolas.birlirakis@cnrs.fr (N.B.); francoise.gueritte@wanadoo.fr (F.G.)

3 Department of Pharmacy, Faculty of Medicine, University Malaya, Kuala Lumpur 50603, Malaysia; E-Mails: Leongkh@um.edu.my (K.H.L.); khalitmohamad@um.edu.my (K.M.)

$\dagger$ These authors contributed equally to this work. Dedicated to the memory of Dr. Khalit Mohamad.

* Authors to whom correspondence should be addressed; E-Mails: marc.litaudon@cnrs.fr (M.L.); khalijah@um.edu.my (K.A.); Tel.: +33-169-82-30-85 (M.L.); Fax: +33-169-07-72-47 (M.L.); Tel.: +60-3-7967-4064 (K.A.); Fax: +60-3-7967-4193 (K.A.).

Received: 14 November 2013; in revised form: 3 January 2014 / Accepted: 23 January 2014 / Published: 31 January 2014

Abstract: A phytochemical investigation of the methanolic extract of the bark of Endiandra kingiana led to the isolation of seven new tetracyclic endiandric acid analogues, kingianic acids A-G (1-7), together with endiandric acid $M(8)$, tsangibeilin B (9) and endiandric acid (10). Their structures were determined by 1D- and 2D-NMR analysis in combination with HRMS experiments. The structure of compounds $\mathbf{9}$ and $\mathbf{1 0}$ were confirmed by single-crystal X-ray diffraction analysis. These compounds were screened for Bcl-xL and Mcl-1 binding affinities and cytotoxic activity on various cancer cell lines. Compound $\mathbf{5}$ showed moderate cytotoxic activity against human colorectal adeno-carcinoma (HT-29) and lung adenocarcinoma epithelial (A549) cell lines, with $\mathrm{IC}_{50}$ values in the range $15-17 \mu \mathrm{M}$, and compounds 3, 6 and 9 exhibited weak binding affinity for the anti-apoptotic protein Mcl-1. 
Keywords: Endiandra kingiana; lauraceae; endiandric acids; kingianic acids; anti-apoptotic proteins; Bcl-xL; Mcl-1

\section{Introduction}

In our pursuit to discover bioactive phytochemicals from the Malaysia flora [1-3] we recently reported a series of new natural pentacyclic polyketides, named kingianins A-L, isolated from the ethyl acetate extract of the bark of Endiandra kingiana Gamble (Lauraceae) [4]. Several kingianins showed strong binding affinity to the anti-apoptotic protein Bcl-xL, and can therefore be considered as potential anticancer agents [4]. In order to discover additional members of this chemical series or close analogues, we have embarked on the investigation on the methanolic extract of the bark of this species. E. kingiana is a medium-sized evergreen tree, distributed throughout Peninsular Malaysia and Borneo [5-7]. There are about 125 Endiandra species found throughout the tropical regions, including 10 species in Malaysia [5-7], but to our knowledge only three species: E. introrsa, E. anthropophagorum and E. kingiana, have been studied for their phytochemicals. The first one has been reported to produce interesting cyclic polyketides, named endiandric acids, possessing eight chiral centers, and usually isolated as racemic mixtures [8-11]. It was postulated by Black and co-workers that they could be formed by non-enzymatic cyclizations ( $8 \pi \mathrm{e}$ and $6 \pi \mathrm{e}$ electrocyclization followed by Diels-Alder reaction) of a phenylpolyene acid precursor [12-14]. In 1982, Nicolaou's group successfully synthesized the natural endiandric acids by implementing a biomimetic strategy based on Black's hypothesis [14-17]. Endiandric acids and their close derivatives, beilschmiedic acids, are the most characteristic type of natural products isolated from Beilschmiedia and Endiandra species. They were found to exhibit various biological activities, such as antibacterial [18-20], antiplasmodial [20], antitubercular [21], iNOS inhibitory activity [22], and anticancer properties [20,23]. Recently, Williams et al. reported the cytotoxic and antibacterial activities of a series of beilschmiedic acids isolated from a Gabonese Beilschmiedia species against NCI-H460 human lung cancer cells and a clinical isolate of methicillin-resistant Staphylococcus aureus, respectively [23]. Talonsti et al. have also reported recently the isolation of four beilschmiedic acid derivatives, cryptobeilic acids A-D and tsangibeilin B from the bark of Endiandra cryptocaryoides [20]. These compounds showed moderate antiplasmodial activity against the chloroquinone-resistant Plasmodium falciparum strain NF54, and antibacterial activities against Escherichia coli, Acinetobacter calcoaceticus and Pseudomonas stutzeri $[20]$.

The chemical investigation of the methanolic extract of $E$. kingiana bark extract led to the isolation of seven new endiandric acids, kingianic acids $A-G(1-7)$, together with endiandric acid $M(8)$, tsangibeilin B (9) and endiandric acid (10) (compound 10 was only found in the "PubChem" database (CID 71521970) without an associated reference regarding its origin and its spectroscopic data, so this compound is fully described in the present manuscript). Herein, the isolation and structure elucidation of the new tetracyclic endiandric acids; kingianic acids A-G, and the cytotoxic activities, Bcl-xL and Mcl-1 affinities of compounds 1, 3, 5-9 are reported. 


\section{Results and Discussion}

The EtOAc-soluble part of the E. kingiana methanol extract was subjected to silica gel chromatography to afford eight fractions Fr.1-Fr.8. Fractions Fr.4 and Fr.5 were further purified using silica gel as well as semi-preparative HPLC leading to the isolation of the kingianic acid series 1-7, endiandric acid M (8), tsangibeilin B (9) and endiandric acid 10 (Figure 1). All assignments of ${ }^{1} \mathrm{H}-$ and ${ }^{13} \mathrm{C}-\mathrm{NMR}$ data were then established through in depth analysis of 2D-NMR; NOESY, COSY, HSQC and HMBC experiments. All compounds 1-10 were isolated as optically inactive, thus suggesting that they are racemic mixtures and their spectroscopic data were very similar. They all possess a 13 carbon atom fused rings system and they can be divided into two main skeletal types. Six of compounds (1-5, 8) belong to the first type as can be seen in endiandric acid $\mathrm{K}$ and endiandramide $\mathrm{A}$ [22]. While compounds 6, 7, 9 and $\mathbf{1 0}$ belong to the second type, similar to tsangibeilins $\mathrm{A}$ and $\mathrm{B}$ and endiandramide B [22].

Figure 1. Structures of compounds 1-10.

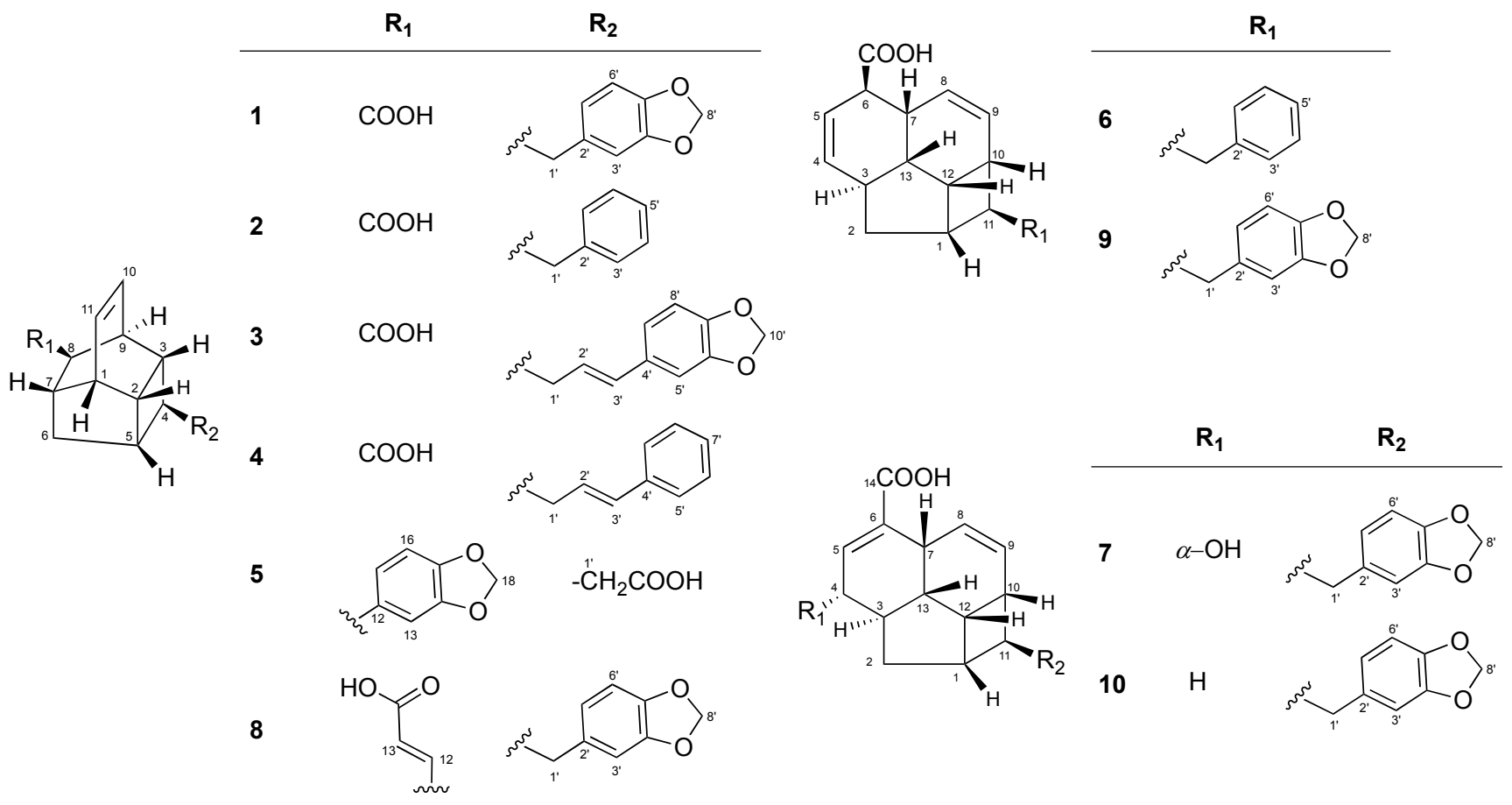

Kingianic acid A (1) was isolated as a colorless oil. The HRESIMS spectrum of $\mathbf{1}$ showed a pseudomolecular ion peak $[\mathrm{M}-\mathrm{H}]^{-}$at $\mathrm{m} / \mathrm{z} 323.1279$ (calcd. 323.1284), consistent with a molecular formula $\mathrm{C}_{20} \mathrm{H}_{20} \mathrm{O}_{4}$ with 11 degrees of unsaturation. Its UV spectrum showed absorption bands at 233 and $286 \mathrm{~nm}$, suggesting the presence of a benzenoid moiety, and its IR spectrum indicated the presence of $\mathrm{OH}\left(3,431 \mathrm{~cm}^{-1}\right)$, carbonyl $\left(1,701 \mathrm{~cm}^{-1}\right)$ and methylenedioxy $\left(1,040\right.$ and $\left.936 \mathrm{~cm}^{-1}\right)$ groups [22]. The ${ }^{13} \mathrm{C}-\mathrm{NMR}$ and DEPT spectra exhibited 20 signals, including 13 methines, three methylenes, and four quaternary carbons. The resonances of the methines at C-1 $\left(\delta_{\mathrm{C}} 41.8\right), \mathrm{C}-2\left(\delta_{\mathrm{C}}\right.$ $39.7), \mathrm{C}-3\left(\delta_{\mathrm{C}} 38.8\right), \mathrm{C}-4\left(\delta_{\mathrm{C}} 40.6\right), \mathrm{C}-5\left(\delta_{\mathrm{C}} 39.8\right), \mathrm{C}-7\left(\delta_{\mathrm{C}} 38.3\right), \mathrm{C}-8\left(\delta_{\mathrm{C}} 48.8\right)$ and C-9 $\left(\delta_{\mathrm{C}} 34.8\right)$, including two olefinic carbons at $\mathrm{C}-10, \mathrm{C}-11$ and a methylene at $\mathrm{C}-6$ observed in the DEPT spectrum, were characteristic of a tetracyclic endiandric acid like endiandric acid $\mathrm{K}$ [22]. The ${ }^{1} \mathrm{H}$ and ${ }^{13} \mathrm{C}-\mathrm{NMR}$ 
spectra of 1 (Table 1) were also similar to those of endiandric acid $\mathrm{K}$ [22], except for the methylene proton signals $\left[\delta_{\mathrm{H}} 2.72\left(\mathrm{~m}, \mathrm{H}-1^{\prime} \mathrm{a}\right) ; 2.78\left(\mathrm{~m}, \mathrm{H}-1^{\prime} \mathrm{b}\right)\right]$. This group is placed between $\mathrm{C}-4$ of the tetracylic acid moiety and C-2' of the benzenoid moiety in $\mathbf{1}$, instead of three methylenes in endiandric acid $\mathrm{K}$.

Table 1. ${ }^{1} \mathrm{H}(600 \mathrm{MHz})$ and ${ }^{13} \mathrm{C}(150 \mathrm{MHz}) \mathrm{NMR}$ data of compounds $\mathbf{1}-\mathbf{3}\left(\mathrm{CDCl}_{3}\right)$.

\begin{tabular}{|c|c|c|c|c|c|c|}
\hline \multirow{2}{*}{ Position } & \multicolumn{2}{|l|}{1} & \multicolumn{2}{|l|}{2} & \multicolumn{2}{|l|}{3} \\
\hline & $\delta_{\mathrm{H}}(J$ in $\mathrm{Hz})$ & $\boldsymbol{\delta}_{\mathbf{c}}$ & $\delta_{\mathrm{H}}(J$ in $\mathrm{Hz})$ & $\boldsymbol{\delta}_{\mathrm{c}}$ & $\delta_{\mathrm{H}}(J$ in $\mathrm{Hz})$ & $\delta_{c}$ \\
\hline 1 & $2.71 \mathrm{~m}$ & 41.8 & $2.72 \mathrm{dd}(1.62,5.1)$ & 41.8 & $2.41 \mathrm{~m}$ & 39.9 \\
\hline 2 & $2.42 \mathrm{dt}(8.5,5.5)$ & 39.7 & $2.44 \mathrm{dt}(9.3,3.7)$ & 39.7 & $2.72 \mathrm{~m}$ & 41.8 \\
\hline 3 & $1.73 \mathrm{~m}$ & 38.8 & $1.76 \mathrm{~m}$ & 38.9 & $1.74 \mathrm{~m}$ & 38.9 \\
\hline 4 & $2.00 \mathrm{t}(8.5)$ & 40.6 & $2.07 \mathrm{t}(8.0)$ & 40.2 & $1.85 \mathrm{t}(7.5)$ & 39.0 \\
\hline 5 & $2.34 \mathrm{t}(6.5)$ & 39.8 & $2.37 \mathrm{t}(6.0)$ & 39.9 & $2.38 \mathrm{~m}$ & 39.8 \\
\hline 6 & $\begin{array}{c}1.55 \mathrm{~d}(13.0) \\
1.90 \mathrm{ddd}(13.0,7.5,5.5)\end{array}$ & 38.5 & $\begin{array}{c}1.54 \mathrm{~d}(12.8) \\
1.90 \mathrm{ddd}(13.0,7.4,5.4)\end{array}$ & 38.4 & $\begin{array}{c}1.58 \mathrm{~d}(12.8) \\
1.93 \mathrm{dt}(7.1,12.9)\end{array}$ & 38.4 \\
\hline 7 & $2.57 \mathrm{t}(5.0)$ & 38.3 & $2.56 \mathrm{t}(4.9)$ & 38.3 & $2.57 \mathrm{t}(5.5)$ & 38.3 \\
\hline 8 & $2.86 \mathrm{~d}(3.5)$ & 48.8 & $2.87 \mathrm{~d}(2.6)$ & 48.8 & $2.89 \mathrm{~d}(3.2)$ & 48.6 \\
\hline 9 & $2.98 \mathrm{dt}(7.0,4.0)$ & 34.8 & $2.98 \mathrm{~m}$ & 34.8 & $3.05 \mathrm{t}(3.6)$ & 34.8 \\
\hline 10 & $6.22 \mathrm{t}(4.0)$ & 131.3 & $6.22 \mathrm{~m}$ & 131.3 & $6.24 \mathrm{t}(3.7)$ & 131.9 \\
\hline 11 & $6.22 \mathrm{t}(4.0)$ & 132.0 & $6.22 \mathrm{~m}$ & 132.0 & $6.24 \mathrm{t}(3.7)$ & 132.3 \\
\hline $1^{\prime}$ & $\begin{array}{l}2.72 \mathrm{~m} \\
2.78 \mathrm{~m}\end{array}$ & 41.7 & $\begin{array}{l}2.83 \mathrm{~m} \\
2.86 \mathrm{~m}\end{array}$ & 41.9 & $2.35 \mathrm{~m}$ & 39.3 \\
\hline $2^{\prime}$ & - & 134.7 & - & 140.9 & $6.02 \mathrm{dt}(6.9,15.7)$ & 126.9 \\
\hline $3^{\prime}$ & $6.66 \mathrm{~s}$ & 109.1 & $7.15 \mathrm{~d}(7.1)$ & 128.7 & $6.29 \mathrm{~d}(15.7)$ & 130.5 \\
\hline $4^{\prime}$ & - & 147.5 & $7.28 \mathrm{t}(7.6)$ & 128.3 & - & 131.4 \\
\hline $5^{\prime}$ & - & 145.7 & $7.19 \mathrm{t}(7.3)$ & 125.8 & $6.90 \mathrm{~d}(1.2)$ & 108.4 \\
\hline $6^{\prime}$ & $6.72 \mathrm{~d}(8.0)$ & 108.1 & $7.28 \mathrm{t}(7.6)$ & 128.4 & - & 148.0 \\
\hline $7^{\prime}$ & $6.60 \mathrm{~d}(8.0)$ & 121.5 & $7.15 \mathrm{~d}(7.1)$ & 128.6 & - & 146.7 \\
\hline $8^{\prime}$ & $5.92 \mathrm{~s}$ & 100.8 & & & $6.73 \mathrm{~d}(8.0)$ & 108.2 \\
\hline $9^{\prime}$ & & & & & $6.76 \mathrm{~d}(8.0)$ & 120.3 \\
\hline $10^{\prime}$ & & & & & $5.94 \mathrm{~s}$ & 101.0 \\
\hline $\mathrm{C}=\mathrm{O}$ & - & 179.3 & - & 179.4 & - & 178.3 \\
\hline
\end{tabular}

The ${ }^{1} \mathrm{H}$ NMR of 1 revealed two $c i s$ olefinic proton signals at $\delta_{\mathrm{H}} 6.22(\mathrm{t}, J=4.0 \mathrm{~Hz}, \mathrm{H}-10$ and $\mathrm{H}-11)$. The three aromatic protons resonated as one singlet at $\delta_{\mathrm{H}} 6.66\left(\mathrm{~s}, \mathrm{H}-3^{\prime}\right)$ and two ortho-coupled doublets $\delta_{\mathrm{H}} 6.72\left(\mathrm{~d}, J=8.0 \mathrm{~Hz}, \mathrm{H}-6^{\prime}\right)$ and $6.60\left(\mathrm{~d}, J=8.0 \mathrm{~Hz}, \mathrm{H}-7^{\prime}\right)$ suggested the presence of a 1,3,4-trisubstituted aromatic ring. In addition, proton signals at $\delta_{\mathrm{H}} 5.92\left(\mathrm{~s}, \mathrm{H}-8^{\prime}\right)$ confirmed the presence of the methylenedioxy group. As determined from the HMBC spectrum, the long-range correlations between $\mathrm{H}-7\left(\delta_{\mathrm{H}} 2.57\right)$ and $\mathrm{H}-8\left(\delta_{\mathrm{H}} 2.86\right)$ to $\mathrm{COOH}\left(\delta_{\mathrm{C}} 179.3\right)$ indicated the presence of carboxylic acid moiety attached to $\mathrm{C}-8$ position of the tetracyclic moiety. Finally, the correlations of H-3'/C-1' $\left(\delta_{\mathrm{C}} 41.7\right), \mathrm{H}-7^{\prime} / \mathrm{C}-1^{\prime}, \mathrm{H}-1^{\prime} / \mathrm{C}-2^{\prime}\left(\delta_{\mathrm{C}} 134.7\right)$ and $\mathrm{H}-5 / \mathrm{C}-1^{\prime}$ determined the connection of the methylenedioxyphenyl moiety to the tetracycle core through $\mathrm{C}-1$ ' (Figure 2). The relative configuration of 1 was deduced from NOESY analysis (Figure 3) in combination with biogenetic consideration and comparison with endiandric acid K [22]. Based on NOESY spectrum, the $\alpha$-orientation of H-9 was deduced from the correlations of $\mathrm{H}-9 / \mathrm{H}-8$ and $\mathrm{H}-8 / \mathrm{H}-4$. In contrast, other correlations between $\mathrm{H}-3 / \mathrm{H}-2$, $\mathrm{H}-2 / \mathrm{H}-1$ and $\mathrm{H}-5 / \mathrm{H}-6 \beta$ and $\mathrm{H}-6 \beta / \mathrm{H}-7$ suggested that protons $\mathrm{H}-1, \mathrm{H}-2, \mathrm{H}-3, \mathrm{H}-5$ and $\mathrm{H}-7$ to be 
$\beta$-oriented. Thus, the relative configuration was assigned as rel-(1RS, $2 R S, 3 R S, 4 S R, 5 S R, 7 S R, 8 R S$, $9 S R$ ), the same as that of endiandric acid $\mathrm{K}[22]$.

Figure 2. Key ${ }^{1} \mathrm{H}-{ }^{1} \mathrm{HCOSY}$ (bold) and $\operatorname{HMBC}\left({ }^{1} \mathrm{H} \rightarrow{ }^{13} \mathrm{C}\right)$ correlations of $\mathbf{1}, \mathbf{6}$ and $\mathbf{1 0}$.

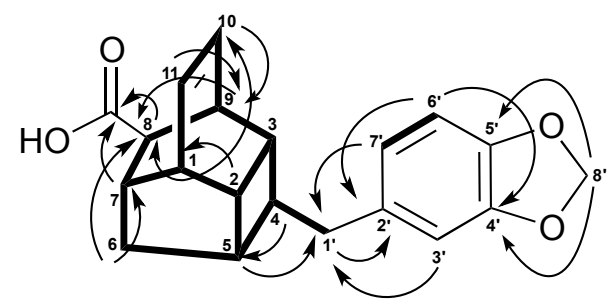

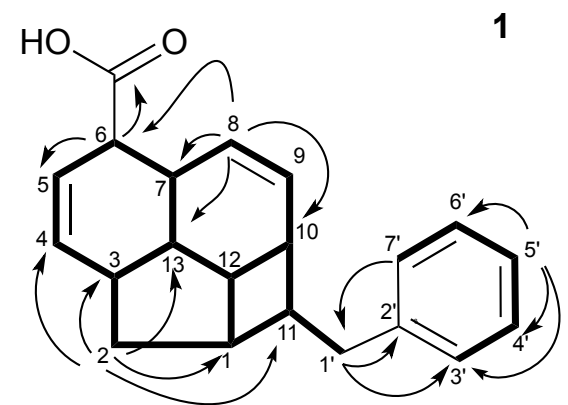

6

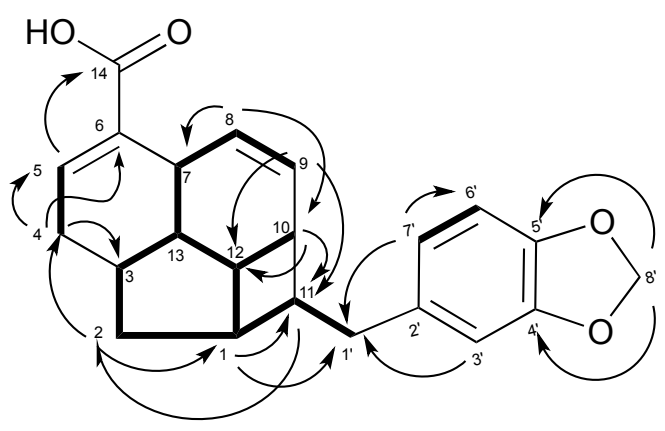

10

Figure 3. Selected NOESY $\left({ }^{1} \mathrm{H} \leftrightarrow{ }^{1} \mathrm{H}\right)$ correlations of $\mathbf{1}, \mathbf{6}$ and $\mathbf{1 0}$.

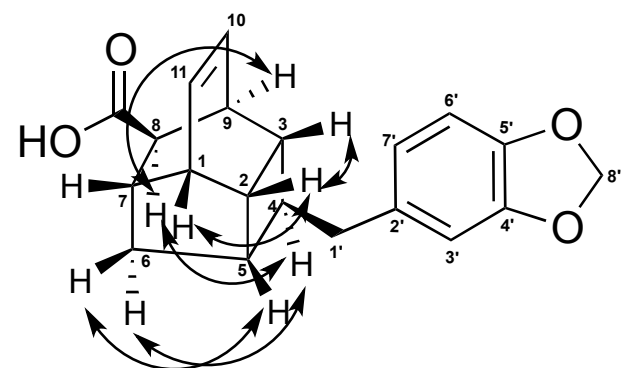

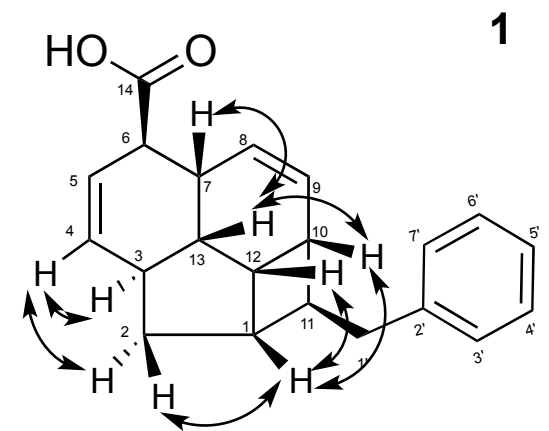

6

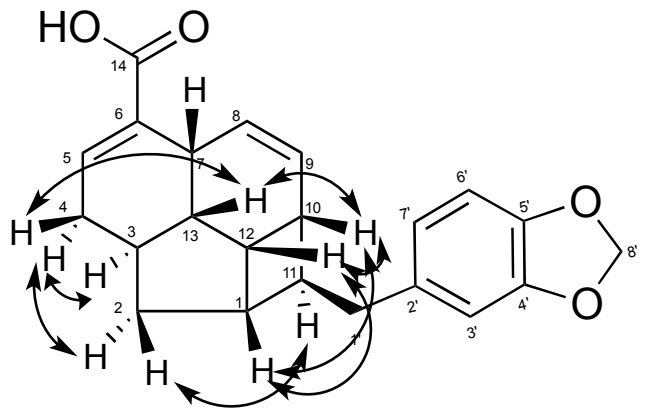

10

Kingianic acid B (2) was obtained as a yellowish oil. The HRESIMS of 2 showed a pseudomolecular ion peak $[\mathrm{M}-\mathrm{H}]^{-}$at $m / z 279.1398$ (calcd. 279.1385) which indicated the molecular formula $\mathrm{C}_{19} \mathrm{H}_{20} \mathrm{O}_{2}$, and was consistent with 10 degrees of unsaturation. The UV, IR, ${ }^{1} \mathrm{H}$ and ${ }^{13} \mathrm{C}-\mathrm{NMR}$ data (Table 1) were similar to those of 1 . The ${ }^{13} \mathrm{C}$-NMR and DEPT spectra exhibited 11 signals for an endiandric acid moiety, including the presence of 10 methines and one methylene group. The NMR 
data of compound $\mathbf{2}$ were nearly identical to those of $\mathbf{1}$, except for the substituent at C-4, indicating that the methylenedioxyphenyl in $\mathbf{1}$ was replaced by a monosubstituted phenyl moiety in $2\left[\delta_{\mathrm{H}} 7.15\right.$ (d, $J=7.1 \mathrm{~Hz}, \mathrm{H}-3^{\prime}$ and H-7'); 7.28 (t, $J=7.6 \mathrm{~Hz}, \mathrm{H}-4^{\prime}$ and H-6') and 7.19 (t, $\left.J=7.3 \mathrm{~Hz}, \mathrm{H}-5^{\prime}\right)$ ]. Analysis of the NOESY spectrum indicated that $\mathbf{2}$ possess the same relative configuration as $\mathbf{1}$.

Kingianic acids C (3) and D (4) were isolated as yellowish oils. The molecular formula of 3 $\left(\mathrm{C}_{22} \mathrm{H}_{22} \mathrm{O}_{4}\right)$ and $4\left(\mathrm{C}_{21} \mathrm{H}_{22} \mathrm{O}_{2}\right)$ were established by the $[\mathrm{M}-\mathrm{H}]^{-}$ion peaks at $\mathrm{m} / \mathrm{z} 349.1439$ (calcd. 349.1440) and 305.1539 (calcd. 305.1542) in the HRESIMS, respectively. The ${ }^{1} \mathrm{H}$ and ${ }^{13} \mathrm{C}$-NMR data (Tables 1 and 2) of compounds $\mathbf{3}$ and $\mathbf{4}$ were very similar to both $\mathbf{1}$ and $\mathbf{2}$, and the analysis of the COSY correlations of $\mathbf{3}$ and $\mathbf{4}$ revealed the characteristic signals for a tetra-fused ring system as seen in compounds 1 and 2 . The presence of a carbonyl group was indicated by the absorption band at 1,697 $\mathrm{cm}^{-1}$ in the IR spectrum of 3 and 1,693 $\mathrm{cm}^{-1}$ for 4, and confirmed by signals at $\delta_{\mathrm{C}} 178.3$ and 177.5 in their ${ }^{13} \mathrm{C}-\mathrm{NMR}$ spectra, respectively. In the HMBC spectra of $\mathbf{3}$ and $\mathbf{4}$, the correlations from $\mathrm{H}-8$ and $\mathrm{H}-7$ to $\mathrm{COOH}$ confirmed the connectivity of the carboxylic acid function. Besides the characteristic tetracyclic moiety, analysis of COSY and HMBC correlations indicated that the methylenedioxyphenyl and monosubstituted phenyl moieties were attached at C-4 in compounds 3 and $\mathbf{4}$, respectively. The geometry of C-2', 3' double bond was assigned as trans on the basis of the coupling constants of H-3' $\left(\delta_{\mathrm{H}} 6.29, \mathrm{~d}, J=15.7 \mathrm{~Hz}\right)$ and $\left(\delta_{\mathrm{H}} 6.38, \mathrm{~d}, J=15.8 \mathrm{~Hz}\right)$ in both compounds (Tables 1 and 2$)$. The NOESY spectra of $\mathbf{3}$ and $\mathbf{4}$, showed correlation between H-8 and H-4 indicating that the benzyl moiety at $\mathrm{C}-4$ assumed a $\beta$-position on the tetracyclic framework. Thus, the relative configuration of $\mathbf{3}$ and $\mathbf{4}$ were determined to be rel-(1RS, 2RS, 3RS, 4SR, 5SR, 7SR, 8RS, 9SR), the same as in compounds 1 and 2.

Kingianic acid E (5) was isolated as a yellowish oil. HRESIMS of 5 gave an $[\mathrm{M}-\mathrm{H}]^{-}$ion at $\mathrm{m} / \mathrm{z}$ 323.1298 (calcd 323.1284), consistent with a molecular formula of $\mathrm{C}_{20} \mathrm{H}_{20} \mathrm{O}_{4}$ with 11 degrees of unsaturation. Its UV and IR spectra were similar to those of 1. A close examination of the NMR spectra of compound $\mathbf{5}$ (Table 2) indicated that $\mathbf{5}$ possessed the same tetracyclic moiety as $\mathbf{1}$, but with different substituents at $\mathrm{C}-4$ and $\mathrm{C}-8$. The two substituents consisted of an acetic acid group $\left[\delta_{\mathrm{H}} 2.64\right.$ $\left.\left(m, \mathrm{H}_{2}-1^{\prime}\right) ; \delta_{\mathrm{C}} 176.9(\mathrm{COOH})\right]$ and a methylenedioxyphenyl moiety $\left(\delta_{\mathrm{H}} 6.61, \mathrm{~s}, \mathrm{H}-13 ; 6.67, \mathrm{~d}, J=8.0\right.$ $\mathrm{Hz}, \mathrm{H}-16$; 6.54, d, $J=8.0 \mathrm{~Hz}, \mathrm{H}-17$; and 5.89, $s, \mathrm{H}-18)$. Their location at C-4 and C-8, respectively, was deduced from COSY and HMBC correlations. The COSY correlation between $\mathrm{H}-4$ and $\mathrm{H}_{2}-1^{\prime}$ on one hand, and $\mathrm{HMBC}$ correlations from $\mathrm{H}-8\left(\delta_{\mathrm{H}} 3.25\right)$ to $\mathrm{C}-12\left(\delta_{\mathrm{C}} 140.2\right)$, and from $\mathrm{H}-13\left(\delta_{\mathrm{H}} 6.61\right) / \mathrm{H}-17$ $\left(\delta_{\mathrm{H}} 6.54\right)$ to $\mathrm{C}-8\left(\delta_{\mathrm{C}} 47.9\right)$ on the other hand, confirmed the location of the acetic acid group and the methylenedioxyphenyl moiety at $\mathrm{C}-4$ and $\mathrm{C}-8$, respectively. The relative configuration of compound $\mathbf{5}$, named kingianic acid E, was fixed by a NOESY experiment as the same as that of compound 1.

The molecular formula $\mathrm{C}_{21} \mathrm{H}_{22} \mathrm{O}_{2}$ of kingianic acid $\mathrm{F}$ (6) was determined by HRESIMS analysis; 305.1557 (calcd 305.1542), for which 10 degrees of unsaturation could be deduced. The UV spectrum of 6 showed characteristic absorption bands at 232 and $288 \mathrm{~nm}$ suggesting the presence of a benzenoid moiety, and its IR spectrum showed absorption bands at 3,432 $\mathrm{cm}^{-1}$ for an $\mathrm{OH}$ group and 1,696 $\mathrm{cm}^{-1}$ for a carbonyl group. The ${ }^{13} \mathrm{C}$-NMR and DEPT spectrum, which showed 21 signals for two methylenes, 16 methines (nine olefinic), and two quaternary and a carbonyl carbon that were characteristic of the tetracyclic endiandric acid skeleton as seen in tsangibeilin B (9) [22]. The ${ }^{1} \mathrm{H}$ and ${ }^{13} \mathrm{C}-\mathrm{NMR}$ spectra of compound 6 were reminiscent to those of $\mathbf{9}$, except for the absence of signal for a methylenedioxy group in $\mathbf{6}$ and the appearance of five aromatic proton and carbon signals, thus suggesting that the methylenedioxyphenyl moiety was replaced by a monosubstituted phenyl moiety. All carbon-carbon 
connectivities of compound $\mathbf{6}$ were determined through a thorough analysis of 2D NMR spectra (Figures 2 and 3), and comparison with those of tsangibeilin B (9). The location of the COOH group at C-6, and the phenyl moiety at C-11, was confirmed by HMBC correlation from H-6 to the carbonyl carbon at $\delta_{\mathrm{C}} 179.4$, and from COSY correlations between $\mathrm{H}-11$ and $\mathrm{H}_{2}-1$ ', respectively. The relative configuration of $\mathbf{6}$ was ascertained by the careful inspection of NOESY spectrum (Figure 3) and biogenesis considerations of tsangibeilin $\mathrm{B}$ as reference [22].

Table 2. ${ }^{1} \mathrm{H}(600 \mathrm{MHz})$ and ${ }^{13} \mathrm{C}(150 \mathrm{MHz}) \mathrm{NMR}$ data of compounds 4 and $5\left(\mathrm{CDCl}_{3}\right)$.

\begin{tabular}{|c|c|c|c|c|}
\hline \multirow{2}{*}{ Position } & \multicolumn{2}{|l|}{4} & \multicolumn{2}{|l|}{5} \\
\hline & $\delta_{\mathrm{H}}(J$ in $\mathrm{Hz})$ & $\delta_{\mathbf{c}}$ & $\delta_{\mathrm{H}}(J$ in $\mathrm{Hz})$ & $\boldsymbol{\delta}_{\mathrm{c}}$ \\
\hline 1 & $2.73 \mathrm{~m}$ & 41.9 & $2.76 \mathrm{dd}(5.1,10.8)$ & 42.4 \\
\hline 2 & $2.40 \mathrm{~m}$ & 39.8 & $2.46 \mathrm{~m}$ & 39.9 \\
\hline 3 & $1.76 \mathrm{~m}$ & 39.0 & $2.62 \mathrm{~m}$ & 40.3 \\
\hline 4 & $1.88 \mathrm{t}(7.4)$ & 38.9 & $2.44 \mathrm{~m}$ & 35.3 \\
\hline 5 & $2.36 \mathrm{t}(7.4)$ & 39.9 & $2.37 \mathrm{t}(6.6)$ & 40.2 \\
\hline 6 & $\begin{array}{c}1.61 \mathrm{~d}(12.7) \\
1.93 \mathrm{~m}\end{array}$ & 38.4 & $\begin{array}{c}1.74 \mathrm{~d}(12.6) \\
1.94 \mathrm{~m}\end{array}$ & 39.3 \\
\hline 7 & $2.58 \mathrm{t}(5.1)$ & 38.3 & $2.31 \mathrm{t}(4.6)$ & 43.1 \\
\hline 8 & $2.90 \mathrm{~d}(3.8)$ & 48.6 & $3.25 \mathrm{~d}(2.5)$ & 47.9 \\
\hline 9 & $3.06 \mathrm{t}(3.8)$ & 34.8 & $2.72 \mathrm{~m}$ & 39.6 \\
\hline 10 & $6.23 \mathrm{~d}(3.1)$ & 131.4 & $5.93 \mathrm{t}(7.0)$ & 132.3 \\
\hline 11 & $6.24 \mathrm{~d}(3.0)$ & 131.9 & $6.29 \mathrm{t}(7.3)$ & 130.5 \\
\hline 12 & & & & 140.2 \\
\hline 13 & & & $6.61 \mathrm{~s}$ & 109.5 \\
\hline 14 & & & & 146.9 \\
\hline 15 & & & & 145.2 \\
\hline 16 & & & $6.67 \mathrm{~d}(8.0)$ & 107.4 \\
\hline 17 & & & $6.54 \mathrm{~d}(8.0)$ & 121.6 \\
\hline 18 & & & $5.89 \mathrm{~s}$ & 100.7 \\
\hline $1^{\prime}$ & $2.43 \mathrm{~m}$ & 39.4 & $2.64 \mathrm{~m}$ & 40.4 \\
\hline $2^{\prime}$ & $6.19 \mathrm{~m}$ & 128.7 & & \\
\hline $3^{\prime}$ & $6.38 \mathrm{~d}(15.8)$ & 131.0 & & \\
\hline $4^{\prime}$ & - & 137.7 & & \\
\hline $5^{\prime}$ & $7.35 \mathrm{~d}(7.2)$ & 126.0 & & \\
\hline $6^{\prime}$ & $7.30 \mathrm{t}(7.6)$ & 128.5 & & \\
\hline $7^{\prime}$ & $7.20 \mathrm{t}(7.3)$ & 127.0 & & \\
\hline $8^{\prime}$ & $7.30 \mathrm{t}(7.6)$ & 128.5 & & \\
\hline $9^{\prime}$ & $7.35 \mathrm{~d}(7.2)$ & 126.0 & & \\
\hline $10^{\prime}$ & & & & \\
\hline $\mathrm{C}=\mathrm{O}$ & - & 177.5 & & 176.9 \\
\hline
\end{tabular}


Thus, the relative configuration of $\mathbf{6}$, named kingianic acid $F$ or $11\left\{1^{\prime}-[\right.$ phenyl] $\}$ tetracyclo[5.4.2. $\left.0^{3,13} \cdot 0^{10,12}\right]$ trideca-4,8-dien-6-carboxylic acid (kingianic acid F), was assigned as rel(1RS, 2RS, 3RS, 4SR, 5SR, 7SR, 8RS, 9SR), same as that of tsangibeilin B (9) [22].

Kingianic acid G (7) was obtained as a yellowish oil. The negative-mode HREIMS exhibited a quasi-molecular ion peak at $\mathrm{m} / \mathrm{z} 365.1401[\mathrm{M}-\mathrm{H}]^{-}$(calcd. 365.1389), which suggested the molecular formula of $\mathrm{C}_{22} \mathrm{H}_{22} \mathrm{O}_{5}$, and implied 12 degrees of unsaturation. The UV absorption bands at $\lambda_{\max } 234$ and $286 \mathrm{~nm}$ confirmed the presence of a benzenoid nucleus [23]. The absorption bands at 2,600-3,300, $1,687,1,632,1,040$ and $937 \mathrm{~cm}^{-1}$ in the IR spectrum revealed the presence of $\mathrm{OH}, \mathrm{C}=\mathrm{O}, \mathrm{C}=\mathrm{C}$ and O-CH $2-\mathrm{O}$ groups, respectively. The ${ }^{1} \mathrm{H}$ and ${ }^{13} \mathrm{C}$-NMR data of 7 were similar to those of $\mathbf{1 0}$, suggesting that they both share a common tetracyclic endiandric acid skeleton, except for the presence of an $\alpha-\mathrm{OH}$ at $\delta_{\mathrm{H}} 4.23(\mathrm{~d}, J=9.8 \mathrm{~Hz}, \mathrm{H}-4)$ in 7 . The location of this hydroxy group at C-4 was deduced from the COSY correlations between H-3/H-5 and H-4, and HMBC correlations from H-2a $\left(\delta_{\mathrm{H}} 1.29\right), \mathrm{H}-3$ and $\mathrm{H}-13$ to $\mathrm{C}-4$. The relative configuration of the stereogenic centers was established by biogenetic considerations [24], analysis of the NOESY spectrum and comparison with NMR data reported in the literature [23]. NOESY correlations between $\mathrm{H}-12$ and $\mathrm{H}-1 / \mathrm{H}-10 / \mathrm{H}-13, \mathrm{H}-1$, and between $\mathrm{H}-7$ and $\mathrm{H}-$ 8/H-13 confirmed that protons $\mathrm{H}-1, \mathrm{H}-7, \mathrm{H}-10, \mathrm{H}-12$ and $\mathrm{H}-13$ are all cofacial, arbitrarily assigned as $\beta$-oriented. Since cross peaks between $\mathrm{H}-4$ at $\delta_{\mathrm{H}} 4.23$ and $\mathrm{H}-2 \mathrm{a}$ and $\mathrm{H}-2 \mathrm{~b}$, at $\delta_{\mathrm{H}} 1.29$ and 1.79 respectively, were equally intense, the relative configuration at $\mathrm{C}-4$ could not be deduced from the NOESY spectrum. However, comparison of NMR data of kingianic acid G (7) with data reported in the literature for beilschmiedic acids $\mathrm{H}$ and I allowed the assignment of the 4-OH configuration [23]. Indeed, since compound 7 possesses similar ${ }^{13} \mathrm{C}$ chemical shifts to beilschmiedic acid $\mathrm{H}$ for carbons C-3, C-4 and C-5 $\left(\delta_{\mathrm{C}} 44.1,73.6,145.6\right.$, respectively for $7 ; \delta_{\mathrm{C}} 45.1,74.5$ and 145.8 , respectively for beilschmiedic acid $\mathrm{H}$ ), it can be deduced that the hydroxy group is $\alpha$-oriented, as was the case for beilschmiedic acid $\mathrm{H}$ [23]. In the case of beilschmiedic acid $\mathrm{I}$, having a $\beta$-oriented hydroxy group at C-4, chemical shifts of C-3, C-4 and C-5 are more shielded; 43.1, 65.9 and 141.5 ppm, respectively [23]. Thus, kingianic acid $\mathrm{G}(7)$ was proposed to have the same relative configuration as beilschmiedic acid $\mathrm{H}$.

Compound $\mathbf{1 0}$ was obtained as an amorphous solid. The HRESIMS spectrum of $\mathbf{1 0}$ showed a pseudomolecular ion peak $[\mathrm{M}-\mathrm{H}]^{-}$at $\mathrm{m} / \mathrm{z}$ 349.1431(calcd. 349.1440), consistent with a molecular formula of $\mathrm{C}_{22} \mathrm{H}_{22} \mathrm{O}_{4}$, with 12 degrees of unsaturation. Its IR spectrum showed strong absorption bands at $1,685 \mathrm{~cm}^{-1}$ for $\mathrm{C}=\mathrm{O}$, and $1,630 \mathrm{~cm}^{-1}$ for $\mathrm{C}=\mathrm{C}$, and $\mathrm{UV}$ absorption bands at $\lambda_{\max } 234$ and $286 \mathrm{~nm}$ suggesting the presence of a benzenoid moiety. The ${ }^{13} \mathrm{C}-\mathrm{NMR}$ spectrum of $\mathbf{1 0}$ (Table 3 ) contained 22 carbons signals, which were sorted by DEPT-135 NMR and HSQC into 5 quaternary carbons, 14 methines and 4 methylene groups. Resonances of methines at $\delta_{\mathrm{C}} 40.9$ (C-1), 35.6 (C-3), 144.6 (C-5), 33.3 (C-7), 127.1 (C-8), 127.0 (C-9), 33.2 (C-10), 46.9 (C-11), 34.0 (C-12) and 42.2 (C-13), and methylene groups at $\delta_{\mathrm{C}} 37.0(\mathrm{C}-2)$ and $32.2(\mathrm{C}-4)$ observed in the DEPT spectrum, were characteristic of a tetracyclic endiandric acid skeleton as seen in cryptobeilic acids A-D [20]. The ${ }^{13} \mathrm{C}-\mathrm{NMR}$ spectrum showed also signals of a conjugated carbonyl group at $\delta_{\mathrm{C}} 178.0(\mathrm{COOH})$, an olefinic quaternary carbon at $\delta_{\mathrm{C}} 134.6$ (C-6) and carbons of a substituted methylenedioxybenzyl moiety (C-1'-C-8'). The presence of olefinic methines in $\mathbf{1 0}$ was confirmed by the ${ }^{1} \mathrm{H}-\mathrm{NMR}$ spectrum (Table 3 ), which showed a broad singlet of proton $\mathrm{H}-5$ at $\delta_{\mathrm{H}} 7.23$ (brs, $\mathrm{H}-5$ ) and a pair of protons appearing as doublet at $\delta_{\mathrm{H}} 5.39(\mathrm{~d}, J=10.0 \mathrm{~Hz}, \mathrm{H}-8)$ and $5.54(\mathrm{~d}, J=10.0 \mathrm{~Hz}, \mathrm{H}-9)$. The ortho coupled proton H-6' and H-7' resonated as a pair of doublets at $\delta_{\mathrm{H}} 6.71\left(\mathrm{~d}, J=7.9 \mathrm{~Hz}, \mathrm{H}-6^{\prime}\right)$ and $6.60\left(\mathrm{~d}, J=7.9 \mathrm{~Hz}, \mathrm{H}-7^{\prime}\right)$, 
while $\mathrm{H}-3^{\prime}$ appeared as a singlet at $\delta_{\mathrm{H}} 6.65\left(\mathrm{~s}, \mathrm{H}-3^{\prime}\right)$. In addition, protons signal at $\delta_{\mathrm{H}} 5.91\left(\mathrm{~s}, \mathrm{H}-8^{\prime}\right)$ confirmed the presence of the methylenedioxy group. HMBC correlations (Figure 2) from H-5 to C-6 $\left(\delta_{\mathrm{C}} 134.6\right)$ and $\mathrm{COOH}\left(\delta_{\mathrm{C}} 178.0\right)$, and from $\mathrm{H}-8$ to $\mathrm{C}-6$ established the location of the carboxylic group at $\mathrm{C}-6$. The attachment of the methylenedioxybenzyl moiety at $\mathrm{H}-11$ was confirmed by the correlation from $\mathrm{H}-11$ to $\mathrm{C}-2$ ', and from $\mathrm{H}-1$ ' to $\mathrm{C}-10$ and $\mathrm{C}-1$. The relative configuration of the asymmetric carbons was established by NOESY analysis (Figure 3) and confirmed by X-ray crystallographic analysis (see Supporting Information). Therefore, the relative configuration of H-1, H-3, H-6, H-7, $\mathrm{H}-10, \mathrm{H}-11, \mathrm{H}-12$, and $\mathrm{H}-13$ was assigned as rel-(1SR,3RS,7RS,10RS,11SR,12SR,13SR), same as that of beilschmiedic acid $\mathrm{H}[23]$.

Table 3. ${ }^{1} \mathrm{H}(600 \mathrm{MHz})$ and ${ }^{13} \mathrm{C}(150 \mathrm{MHz}) \mathrm{NMR}$ data of compounds $\mathbf{6}$, 7, and $\mathbf{1 0}\left(\mathrm{CDCl}_{3}\right)$.

\begin{tabular}{|c|c|c|c|c|c|c|}
\hline \multirow{2}{*}{ Position } & \multicolumn{2}{|l|}{6} & \multicolumn{2}{|l|}{7} & \multicolumn{2}{|l|}{10} \\
\hline & $\delta_{\mathrm{H}}(J$ in $\mathrm{Hz})$ & $\delta_{\mathrm{c}}$ & $\delta_{\mathrm{H}}(J$ in $\mathrm{Hz})$ & $\delta_{\mathbf{c}}$ & $\delta_{\mathrm{H}}(J$ in $\mathrm{Hz})$ & $\delta_{\mathbf{c}}$ \\
\hline 1 & $2.45 \mathrm{~m}$ & 41.0 & $2.48 \mathrm{~m}$ & 40.9 & $2.42 \mathrm{~m}$ & 40.9 \\
\hline 2 & $\begin{array}{l}1.30 \mathrm{dt}(6.3,12.1) \\
1.53 \mathrm{dd}(6.4,11.9)\end{array}$ & 34.7 & $\begin{array}{l}1.29 \mathrm{~m} \\
1.79 \mathrm{~m}\end{array}$ & 35.0 & $\begin{array}{l}1.20 \mathrm{~m} \\
1.53 \mathrm{~m}\end{array}$ & 37.0 \\
\hline 3 & $2.55 \mathrm{~m}$ & 36.9 & $2.08 \mathrm{~m}$ & 44.1 & $2.04 \mathrm{~m}$ & 35.6 \\
\hline 4 & $6.19 \mathrm{~d}(9.7)$ & 134.4 & $4.23 \mathrm{~d}(9.8)$ & 73.6 & $2.08 \mathrm{~m}, 2.47 \mathrm{~m}$ & 32.2 \\
\hline 5 & $5.72 \mathrm{~d}(9.6)$ & 123.9 & $7.03 \mathrm{brs}$ & 145.6 & 7.23 brs & 144.6 \\
\hline 6 & $3.00 \mathrm{~m}$ & 49.0 & - & 134.3 & - & 134.6 \\
\hline 7 & $2.84 \mathrm{~m}$ & 32.8 & $3.23 \mathrm{brs}$ & 33.2 & 3.26 brs & 33.3 \\
\hline 8 & $5.40 \mathrm{~m}$ & 129.8 & $5.43 \mathrm{~d}(10.5)$ & 127.7 & $5.39 \mathrm{~d}(10.0)$ & 127.1 \\
\hline 9 & $5.42 \mathrm{~m}$ & 129.1 & $5.53 \mathrm{~d}(10.5)$ & 126.2 & $5.54 \mathrm{~d}(10.0)$ & 127.0 \\
\hline 10 & $2.39 \mathrm{~m}$ & 34.5 & $2.42 \mathrm{~m}$ & 33.7 & $2.40 \mathrm{~m}$ & 33.2 \\
\hline 11 & $1.82 \mathrm{~m}$ & 46.9 & $1.76 \mathrm{~m}$ & 46.8 & $1.74 \mathrm{~m}$ & 46.9 \\
\hline 12 & $2.70 \mathrm{dd}(7.7,16.2)$ & 32.9 & $2.80 \mathrm{~m}$ & 33.6 & $2.77 \mathrm{~m}$ & 34.0 \\
\hline 13 & $1.73 \mathrm{~m}$ & 42.0 & $1.86 \mathrm{~m}$ & 40.8 & $1.68 \mathrm{~m}$ & 42.2 \\
\hline $1^{\prime}$ & $2.81 \mathrm{~m}$ & 42.9 & $2.71 \mathrm{~d}(8.0)$ & 42.5 & $2.70 \mathrm{~d}(8.0)$ & 42.6 \\
\hline $2^{\prime}$ & - & 140.7 & - & 134.6 & - & 134.6 \\
\hline $3^{\prime}$ & $7.15 \mathrm{~d}(6.8)$ & 128.6 & $6.64 \mathrm{~s}$ & 108.9 & $6.65 \mathrm{~s}$ & 109.0 \\
\hline $4^{\prime}$ & $7.24 \mathrm{t}(6.7)$ & 128.4 & - & 147.5 & - & 147.4 \\
\hline $5^{\prime}$ & $6.20 \mathrm{dt}(2.1,7.3)$ & 125.8 & - & 145.6 & - & 145.6 \\
\hline $6^{\prime}$ & $7.24 \mathrm{t}(6.7)$ & 128.4 & $6.71 \mathrm{~d}(7.9)$ & 108.1 & $6.71 \mathrm{~d}(7.9)$ & 108.0 \\
\hline $7^{\prime}$ & $7.15 \mathrm{~d}(6.8)$ & 128.6 & $6.59 \mathrm{~d}(7.9)$ & 121.3 & $6.60 \mathrm{~d}(7.9)$ & 121.3 \\
\hline $8^{\prime}$ & & & $5.91 \mathrm{~s}$ & 100.7 & $5.91 \mathrm{~s}$ & 100.7 \\
\hline $\mathrm{C}=\mathrm{O}$ & & 179.4 & & 170.3 & & 178.0 \\
\hline
\end{tabular}

Endiandric acid M (8) and tsangibeilin B (9) were readily identified by comparison with literature data [22,25]. The structure and relative configuration of tsangibeilin B (9) were confirmed by single-crystal X-ray analysis (see Supporting Information).

Compounds 1, 3, 5-9 were screened against the anti-apoptotic proteins Bcl-xL and Mcl-1 using fluorescence polarization assays according to Qian and co-workers [26]. Assays are based on the interaction of fluorescein-labeled peptides [the BH3 domain of BAK protein (F-Bak) or BID protein (F-Bid) to Bcl-xL and Mcl-1, respectively]. No binding was detected for Bcl-xL and only weak binding affinity for Mcl-1 (25\%-30\% inhibition at $20 \mu \mathrm{M}$ and $\geq 75 \%$ at $100 \mu \mathrm{M})$ were obtained with compounds 3, 6 and 9 (Table 4). In these assays, amount of compounds 2, 4 and $\mathbf{1 0}$ were not sufficient for this biological evaluation. 
Table 4. Biological activities of compounds 1, 3, 5-9.

\begin{tabular}{cccccccc}
\hline \multirow{2}{*}{ Compounds } & \multicolumn{2}{c}{$\begin{array}{c}\text { Bcl-xL/Bak binding affinity } \\
(\%)\end{array}$} & \multicolumn{2}{c}{$\begin{array}{c}\text { Mcl-1/Bid binding affinity } \\
(\mathbf{\%})\end{array}$} & \multicolumn{3}{c}{$\begin{array}{c}\text { Cytotoxicity } \\
\left(\mathbf{I C}_{\mathbf{5 0}} \text { in } \boldsymbol{\mu M} \text { M,mean } \pm \text { s.d., } \boldsymbol{n}=\mathbf{3}\right)\end{array}$} \\
\cline { 2 - 8 } & $\mathbf{2 0} \boldsymbol{\mu M}$ & $\mathbf{1 0 0} \boldsymbol{\mu M}$ & $\mathbf{2 0} \boldsymbol{\mu M}$ & $\mathbf{1 0 0} \boldsymbol{\mu M}$ & HT-29 & $\mathbf{A 5 4 9}$ & $\mathbf{P C 3}$ \\
\hline $\mathbf{1}$ & $3 \pm 1.5$ & $21 \pm 1.8$ & $3 \pm 2.0$ & $36 \pm 2.3$ & $35.0 \pm 0.2$ & $85.4 \pm 0.2$ & $>100$ \\
$\mathbf{3}$ & $9 \pm 1.5$ & $25 \pm 1.7$ & $30 \pm 2.2$ & $75 \pm 1.1$ & $>100$ & $85.3 \pm 0.2$ & $>100$ \\
$\mathbf{5}$ & $2 \pm 1.4$ & $1 \pm 0.8$ & $3 \pm 1.3$ & $8 \pm 5.5$ & $17.1 \pm 0.1$ & $15.4 \pm 0.2$ & $77.2 \pm 0.2$ \\
$\mathbf{6}$ & $4 \pm 1.6$ & $22 \pm 2.9$ & $28 \pm 3.7$ & $80 \pm 0.7$ & $\mathrm{NT}$ & $\mathrm{NT}$ & $\mathrm{NT}$ \\
$\mathbf{7}$ & $5 \pm 1.3$ & $19 \pm 1.6$ & $8 \pm 1.1$ & $47 \pm 2.9$ & $\mathrm{NT}$ & $\mathrm{NT}$ & $\mathrm{NT}$ \\
$\mathbf{8}$ & 0 & $10 \pm 0.5$ & $4 \pm 0.8$ & $39 \pm 0.9$ & $>100$ & $>100$ & $>100$ \\
$\mathbf{9}$ & $6 \pm 1.5$ & $26 \pm 2.5$ & $25 \pm 2.1$ & $81 \pm 2.4$ & $>100$ & $38.1 \pm 0.1$ & $>100$ \\
U-Bak (Ki) & & $12 \pm 1 \mathrm{nM}$ & & & & & \\
U-Bid (Ki) & & & & $16 \pm 2 \mathrm{nM}$ & & & \\
ABT-737 (Ki) & & $57 \pm 10 \mathrm{nM}$ & & $47 \pm 22 \mathrm{nM}$ & & & \\
Cisplatin & & & & & $70.3 \pm 1.1$ & $36.2 \pm 1.4$ & $44.5 \pm 7.7$ \\
\hline
\end{tabular}

NT: not tested; U-Bak and U-bid correspond to unlabeled peptides Bak and Bid, respectively.

Compounds 1, 3, 5, $\mathbf{8}$ and $\mathbf{9}$ were screened for cytotoxic activity against A549 (lung adenocarcinoma epithelial), HT29 (colorectal adenocarcinoma) and PC3 (prostate adenocarcinoma) cell lines using a 3-(4,5-dimethylthiazol-2-yl)-5-(3-carboxymethoxyphenyl)-2-(4sulfophenyl)- $2 H$-tetrazolium, inner salt (MTS)-based assay (Table 4). Compound 5 showed moderate cytotoxic activity against lung adenocarcinoma epithelial (A549) and colorectal adenocarcinoma cell lines (HT-29) with $\mathrm{IC}_{50}$ of $15.36 \pm 0.19 \mu \mathrm{M}$ and $17.10 \pm 0.11 \mu \mathrm{M}$, respectively. The other compounds showed very weak or devoid of (A549) cytotoxic activity against the cancer cell lines tested. Our results are in agreement with a previous study by Williams, in which some synthetic tetracyclic endiandric acids were not active on prostate adenocarcinoma cancer cells (PC3), but significantly active on lung carcinoma cells [23].

\section{Experimental}

\subsection{General}

Optical rotations were measured on a JASCO P-1020 polarimeter. IR spectra (neat) were taken on a Perkin Elmer RX1 FT-IR spectrometer. 1D $\left({ }^{1} \mathrm{H},{ }^{13} \mathrm{C}\right.$, DEPT) and 2D (COSY, NOESY, HSQC, HMBC) NMR experiments were carried out on a Bruker Avance $600\left(600 \mathrm{MHz}\right.$ for ${ }^{1} \mathrm{H} \mathrm{NMR}, 150 \mathrm{MHz}$ for ${ }^{13} \mathrm{C}$ NMR) spectrometer. Data were analysed via TopSpin software package. Chemical shifts were internally referenced to the solvent signals in $\mathrm{CDCl}_{3}\left({ }^{1} \mathrm{H}, \delta 7.26 ;{ }^{13} \mathrm{C}, \delta 77.0\right)$. High-resolution ESIMS on a Thermoquest TLM LCQ Deca ion-trap mass spectrometer. Silica gels (230-400 mesh) (Merck) were used for column chromatography (CC), and silica gel 60 F-254 (Merck) was used for analytical TLC. Agilent ${ }^{\circledR}$ Eclipse Zorbax C18 column $(250 \times 9.4 \mathrm{~mm}, 3.5 \mu \mathrm{m})$ and Waters ${ }^{\circledR}$ X-Bridge C18 column $(250 \times 10.0 \mathrm{~mm}, 5.0 \mu \mathrm{m})$; were used for semi-preparative HPLC separations using a Waters auto purification system equipped with a sample manager (Waters 2767), a column fluidics organizer, a binary pump (Waters 2525), a UV-Vis diode array detector (190-600 nm, Waters 2996), and a PL-ELS 1000 ELSD Polymer Laboratory detector. X-ray data collection was obtained from a 
BrukerAPEX2; cell refinement: SMART [27]; data reduction: SAINT [27]; program(s) used to solve the structure: SHELXTL [28]; program(s) used to refine structure: SHELXTL [28].

\subsection{Plant Material}

The bark of Endiandra kingiana Gamble was collected at Reserved Forest Sg. Temau, Kuala Lipis, Pahang, Malaysia in May 2006. This plant was identified by T. Leong Eng Botanist University of Malaya. A voucher specimen (KL-5243) has been deposited at the Herbarium of the Department of Chemistry, Faculty of Science, University of Malaya, Kuala Lumpur, Malaysia.

\subsection{Extraction and Isolation}

The air-dried bark of E. kingiana $(1.5 \mathrm{~kg})$ were sliced, ground and extracted with EtOAc $(3 \times 1.5 \mathrm{~L})$ followed by $\mathrm{MeOH}(3 \times 1.5 \mathrm{~L})$ at $40{ }^{\circ} \mathrm{C}$ and 100 bar using a Zippertex static high-pressure, hightemperature extractor developed at the ICSN pilot unit. The methanol extract was concentrated under reduced pressure and was partitioned with EtOAc/ $\mathrm{H}_{2} \mathrm{O}(1: 1, \mathrm{v} / \mathrm{v})$ to afford an EtOAc-soluble fraction (22.5 g) and a $\mathrm{H}_{2} \mathrm{O}$-soluble fraction $(91.7 \mathrm{~g})$. The EtOAc-soluble fraction (22 g) was subjected to column chromatography ( $\mathrm{CC}, 660 \mathrm{~g} \mathrm{SiO}_{2}, 230-400 \mathrm{mesh}$; hexane/dichloromethane/methanol step gradient) to give eight fractions, identified as Fr. 1-Fr. 8.

Fr. 4 (4.3 g) was subjected to $\mathrm{CC}$ (129 g, $\mathrm{SiO}_{2}, 230-400 \mathrm{mesh}$; hexane/AcOEt step gradient) to obtain 20 subfractions base on TLC profile: Fr. 4.1-Fr. 4.20. Fraction Fr. 4.3 (37.8 mg) was separated using semi-preparative $\mathrm{C}_{18} \mathrm{HPLC}$ eluted at $3.5 \mathrm{~mL} / \mathrm{min}$ isocratically with $\mathrm{MeCN}-\mathrm{H}_{2} \mathrm{O}$ 65:35 $+0.1 \%$ formic acid from 5 to $50 \mathrm{~min}\left(\right.$ Agilent ${ }^{\circledR}$ Eclipse Zorbax $\mathrm{C}_{18}$ column $(250 \times 9.4 \mathrm{~mm}, 3.5 \mu \mathrm{m})$. Serial collections afforded $2\left(t_{R} 8.0 \mathrm{~min}, 1.2 \mathrm{mg}\right)$ and $4\left(t_{R} 16.0 \mathrm{~min}, 1.0 \mathrm{mg}\right) .1\left(t_{R} 13.1 \mathrm{~min}, 12.1 \mathrm{mg}\right)$, $\mathbf{6}\left(t_{R} 24.8 \mathrm{~min}, 3.4 \mathrm{mg}\right)$ and $\mathbf{1 0}\left(t_{R} 19.9 \mathrm{~min}, 1.2 \mathrm{mg}\right)$ were purified from the fraction Fr. $4.4(71.0 \mathrm{mg})$ with a semi-preparative C-18 column (Agilent ${ }^{\circledR}$ Eclipse Zorbax C18 column $(250 \times 9.4 \mathrm{~mm}, 3.5 \mu \mathrm{m})$ using $\mathrm{MeCN}-\mathrm{H}_{2} \mathrm{O}$ 65:35 plus $0.1 \%$ formic acid at $3.5 \mathrm{~mL} / \mathrm{min}$. Further analogues were separated from fraction Fr. 4.7 (41.4 mg) and separated using semi-preparative C-18 column (Agilent ${ }^{\circledR}$ Eclipse Zorbax C18 column $(250 \times 9.4 \mathrm{~mm}, 3.5 \mu \mathrm{m})$ using $\mathrm{MeCN}-\mathrm{H}_{2} \mathrm{O} 65: 35$ plus $0.1 \%$ formic acid at $3.5 \mathrm{~mL} / \mathrm{min}$. Serial collections afforded $9\left(t_{R} 14.7 \mathrm{~min}, 1.8 \mathrm{mg}\right)$ and $\mathbf{3}\left(t_{R} 16.4 \mathrm{~min}, 4.4 \mathrm{mg}\right)$. From fraction $\mathrm{Fr} 4.14$ (72.4 mg), $5\left(t_{R} 14.6 \mathrm{~min}, 1.4 \mathrm{mg}\right)$ and $8\left(t_{R} 25.1 \mathrm{~min}, 2.0 \mathrm{mg}\right)$ were isolated using semi-preparative

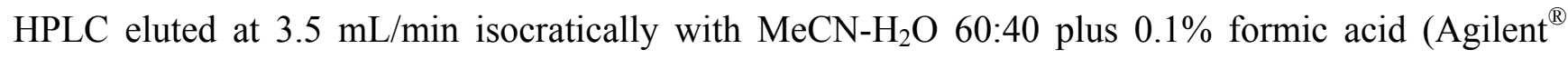
Eclipse Zorbax C18 column $(250 \times 9.4 \mathrm{~mm}, 3.5 \mu \mathrm{m})$. Fr. $5(0.7 \mathrm{~g})$ was subjected to $\mathrm{CC}\left(21 \mathrm{~g}, \mathrm{SiO}_{2}\right.$, 230-400 mesh; hexane/AcOEt step gradient) to obtain 12 subfractions according to their TLC profiles. Fraction Fr. $5.7\left(26.8 \mathrm{mg}\right.$ ) was purified using a semi-preparative $\mathrm{C}_{18}$ column (Waters ${ }^{\circledR} \mathrm{X}$-Bridge $\mathrm{C} 18$ column $(250 \times 10.0 \mathrm{~mm}, 5.0 \mu \mathrm{m})$ using $\mathrm{MeCN}-\mathrm{H}_{2} \mathrm{O} 50: 50$ plus $0.1 \%$ formic acid at $3.0 \mathrm{~mL} / \mathrm{min}$ afforded $7\left(t_{R} 13.4 \mathrm{~min}, 1.5 \mathrm{mg}\right)$.

\subsection{Spectral Data}

Kingianic acid A (1): yellowish oil; $[\alpha]_{D}^{25} \pm 0$ (c 0.20, $\left.\mathrm{CHCl}_{3}\right)$; UV (MeOH) $\lambda_{\max } 233,286 \mathrm{~nm}$; IR (neat) $v_{\max } 3431(\mathrm{OH}), 1701(\mathrm{C}=\mathrm{O}), 1040,936\left(\mathrm{OCH}_{2} \mathrm{O}\right) \mathrm{cm}^{-1} ;{ }^{1} \mathrm{H}-\mathrm{NMR}$ and ${ }^{13} \mathrm{C}-\mathrm{NMR}$, see Table 1; HRESIMS $m / z 323.1279[\mathrm{M}-\mathrm{H}]^{-}$(calcd for $\mathrm{C}_{20} \mathrm{H}_{19} \mathrm{O}_{4}, 323.1284$ ). 
Kingianic acid $B$ (2): yellowish oil; $[\alpha]_{D}^{25} \pm 0$ (c 0.12, $\left.\mathrm{CHCl}_{3}\right) ; \mathrm{UV}(\mathrm{MeOH}) \lambda_{\max } 212,287 \mathrm{~nm}$; IR (neat) $v_{\max } 3432(\mathrm{OH}), 1721(\mathrm{C}=\mathrm{O}) \mathrm{cm}^{-1} ;{ }^{1} \mathrm{H}-\mathrm{NMR}$ and ${ }^{13} \mathrm{C}-\mathrm{NMR}$, see Table 1 ; HRESIMS $\mathrm{m} / \mathrm{z}$ $279.1398[\mathrm{M}-\mathrm{H}]^{-}$(calcd for $\mathrm{C}_{19} \mathrm{H}_{19} \mathrm{O}_{2}, 279.1385$ ).

Kingianic acid $C$ (3): yellowish oil; $[\alpha]_{D}^{25} \pm 0\left(\right.$ c $\left.0.20, \mathrm{CHCl}_{3}\right) ; \mathrm{UV}(\mathrm{MeOH}) \lambda_{\max } 212,290 \mathrm{~nm}$; IR (neat) $v_{\max } 3437(\mathrm{OH}), 1697(\mathrm{C}=\mathrm{O}), 1037,923\left(\mathrm{OCH}_{2} \mathrm{O}\right) \mathrm{cm}^{-1} ;{ }^{1} \mathrm{H}-\mathrm{NMR}$ and ${ }^{13} \mathrm{C}-\mathrm{NMR}$, see Table 1; HRESIMS $m / z 349.1439[\mathrm{M}-\mathrm{H}]^{-}$(calcd for $\mathrm{C}_{22} \mathrm{H}_{21} \mathrm{O}_{4}, 349.1440$ ).

Kingianic acid $D(4)$ : yellowish oil; $[\alpha]_{D}^{25} \pm 0$ (c $\left.0.10, \mathrm{CHCl}_{3}\right) ; \mathrm{UV}(\mathrm{MeOH}) \lambda_{\max } 212,289 \mathrm{~nm}$; IR (neat) $v_{\max } 3440(\mathrm{OH}), 1693(\mathrm{C}=\mathrm{O}) \mathrm{cm}^{-1} ;{ }^{1} \mathrm{H}-\mathrm{NMR}$ and ${ }^{13} \mathrm{C}-\mathrm{NMR}$, see Table 2; HRESIMS $\mathrm{m} / \mathrm{z}$ $305.1539[\mathrm{M}-\mathrm{H}]^{-}$(calcd for $\mathrm{C}_{21} \mathrm{H}_{21} \mathrm{O}_{2}, 305.1542$ ).

Kingianic acid $E$ (5): yellowish oil; $[\alpha]_{D}^{25} \pm 0\left(\right.$ c $\left.0.14, \mathrm{CHCl}_{3}\right)$; UV (MeOH) $\lambda_{\max } 234,286 \mathrm{~nm}$; IR (neat) $v_{\max } 3444(\mathrm{OH}), 1665(\mathrm{C}=\mathrm{O}), 1039,938\left(\mathrm{OCH}_{2} \mathrm{O}\right) \mathrm{cm}^{-1} ;{ }^{1} \mathrm{H}-\mathrm{NMR}$ and ${ }^{13} \mathrm{C}-\mathrm{NMR}$, see Table 2; HRESIMS $m / z 323.1298[\mathrm{M}-\mathrm{H}]^{-}$(calcd for $\mathrm{C}_{20} \mathrm{H}_{19} \mathrm{O}_{4}, 323.1284$ ).

Kingianic acid $F(6)$ : yellowish oil; $[\alpha]_{D}^{25} \pm 0\left(\right.$ c $\left.0.16, \mathrm{CHCl}_{3}\right) ; \mathrm{UV}(\mathrm{MeOH}) \lambda_{\max } 232,288 \mathrm{~nm}$; IR (neat) $v_{\max } 3432(\mathrm{OH}), 1696(\mathrm{C}=\mathrm{O}) \mathrm{cm}^{-1} ;{ }^{1} \mathrm{H}-\mathrm{NMR}$ and ${ }^{13} \mathrm{C}$-NMR, see Table 3; HRESIMS $\mathrm{m} / \mathrm{z}$ $305.1557[\mathrm{M}-\mathrm{H}]^{-}$(calcd for $\mathrm{C}_{21} \mathrm{H}_{21} \mathrm{O}_{2}, 305.1542$ ).

Kingianic acid $G$ (7). Yellowish oil. $[\alpha]_{D}^{25} \pm 0$ (c 0.14, $\left.\mathrm{CHCl}_{3}\right)$. UV (MeOH) $\lambda_{\max } 234,286 \mathrm{~nm}$. IR (neat) $v_{\max }$ 2600-3300 (OH), $1687(\mathrm{C}=\mathrm{O}), 1632(\mathrm{C}=\mathrm{C})$ and 1040, $937\left(\mathrm{OCH}_{2} \mathrm{O}\right) \mathrm{cm}^{-1} .{ }^{1} \mathrm{H}-\mathrm{NMR}$ and ${ }^{13} \mathrm{C}-\mathrm{NMR}$, see Table 3. HREIMS: $m / z$ 365.1401 [M-H] ${ }^{-}$(calcd for $\mathrm{C}_{22} \mathrm{H}_{21} \mathrm{O}_{5}, 365.1389$ ).

Compound 10: Amorphous solid. $[\alpha]_{D}^{25} \pm 0$ (c 0.12, $\mathrm{CHCl}_{3}$ ). UV (MeOH) $\lambda_{\max } 234,286 \mathrm{~nm}$. IR (neat) $v_{\max } 1685(\mathrm{C}=\mathrm{O}), 1630(\mathrm{C}=\mathrm{C})$ and 1039, $935\left(\mathrm{OCH}_{2} \mathrm{O}\right) \mathrm{cm}^{-1} .{ }^{1} \mathrm{H}-\mathrm{NMR}$ and ${ }^{13} \mathrm{C}-\mathrm{NMR}$, see Table 3. HREIMS: $m / z$ 349.1431[M-H] $]^{-}$(calcd for $\mathrm{C}_{22} \mathrm{H}_{21} \mathrm{O}_{4}, 349.1440$ ). A colourless crystal was obtained from $\mathrm{MeOH}$, crystallized in the monoclinic crystal system with $\mathrm{P} 21 / \mathrm{c}$ space group. Cell parameters: $\mathrm{a}=6.141(2) \AA ; \mathrm{b}=23.448(8) \AA ; \mathrm{c}=12.366(4) \AA ; \beta=104.38^{\circ} ; \mathrm{V}=1834.58(8) \AA 3, T 100$ $\mathrm{K}$. For the X-ray crystallographic data of compound $\mathbf{1 0}$ see Supporting Information. Supplementary crystallographic data have been deposited with the CCDC as CCDC-918161.

CCDC-918161 contains the supplementary crystallographic data for this paper. These data can be obtained free of charge via http://www.ccdc.cam.ac.uk/conts/retrieving.html (or from the CCDC, 12 Union Road, Cambridge CB2 1EZ, UK; Fax: +44 1223 336033; E-mail: deposit@ccdc.cam.ac.uk).

\subsection{Bcl-xL and Mcl-1 Binding Affinity Assays}

The binding affinities of compounds for Bcl-xL and Mcl-1 were evaluated by competition against fluorescently labelled reference compounds, Bak and Bid, respectively, as described by Qian et al. [26]. Human 45-84/ C37 Bcl-xL and mouse DN150/DC25 Mcl-1 proteins were recombinantly produced by N. Birlirakis at ICSN. Bak, 5-Carboxyfluorescein-Bak, Bid and 5-carboxyfluorescein-Bid peptides were synthetized by PolyPeptide Laboratories (Strasbourg, France). All sequences are available in the Supporting Information (S37). Unlabeled peptides were dissolved in DMSO (Carlo Erba, Val de Reuil, France) and labelled peptides were diluted in assay buffer, which contained $20 \mathrm{mM} \mathrm{Na}_{2} \mathrm{HPO}_{4}(\mathrm{pH} 7.4)$, 
$50 \mathrm{mM} \mathrm{NaCl}, 2 \mu \mathrm{M}$ EDTA, $0.05 \%$ Pluronic F-68, without pluronic acid for storage at $-20{ }^{\circ} \mathrm{C}$. Liquid handling instrument, Biomek ${ }^{\circledR} \mathrm{NX}$ and Biomeck ${ }^{\circledR} 3000$ (Beckman Coulter, Villepinte, France), were used to add protein and fluorescein-labelled peptides. $15 \mathrm{nM}$ labelled BH3 peptide, $100 \mathrm{nM}$ protein, and $100 \mu \mathrm{M}$ of unlabelled BH3 peptide or compound (first diluted in $10 \mathrm{mM}$ DMSO and then buffer for final concentration from $10^{-9}$ to $10^{-4} \mathrm{M}$ ) into a final volume of $40 \mu \mathrm{L}$ were distributed in a 96 well black polystyrene flat-bottomed microplate (VWR 734-1622). The microplate was then incubated at room temperature for $1 \mathrm{~h}$ and shaken before fluorescent polarization measure. Fluorescence polarization in millipolarization units was measured with a Beckman Coulter Paradigm ${ }^{\circledR}$ using FP cartridge ( $\lambda_{\text {ex }} 485 \mathrm{~nm}, \lambda_{\text {em }} 535 \mathrm{~nm}$ ). The exposure time was $300 \mathrm{~ms}$ per channel. All experimental data were collected using the Biomek Software ${ }^{\circledR}$ (Beckman Coulter, Inc, Brea, CA, USA) and analysed using Microsoft Excel 2010 (Microsoft, Redmond, WA, USA). Results are expressed as binding activity, i.e., percentage of inhibition of the binding of labelled reference compound, or as $K i$, the concentration corresponding to $50 \%$ of such inhibition, and corrected for experimental conditions according to Kenakin rearranged equation [29], which is adapted from Cheng and Prusoff equation [30]. ABT-737, which was kindly provided by O. Nosjean (Institut de Recherche Servier, Croissy, France), and unlabeled peptides Bak and Bid were used as positives control. The performance of the assays was monitored by use of $Z^{\prime}$ factors as described by Zhang et al. [31]. The $Z^{\prime}$ factors for these assays are 0.8 (Bcl-xL/Bak) and 0.7 (Mcl-1/Bid) indicating that they should be robust assays.

\subsection{Cell Viability Assay}

Human cancer cell lines A549 (Lung adenocarcinoma epithelial), HT29 (Colorectal adenocarcinoma) and PC3 (Prostate adenocarcinoma) cells were obtained from the ATCC (Manassas, VA, USA). Cells were grown in RPMI-1640 or DMEM medium with $10 \%$ FBS supplemented with $4 \mathrm{mM}$ L-glutamine and $1 \%$ penicillin-streptomycin. For experimental purposes, the cells growing exponentially and maintained at $70 \%-80 \%$ confluency were used. Cells were seeded into 96-well plates at $10^{4}$ cells/well and allowed to adhere overnight; the medium was then removed. A stock solution of test compound in DMSO was diluted in medium to generate a series of working solutions. Aliquots $(100 \mu \mathrm{L})$ of the working solutions were added to the appropriate test wells to expose cells to the final concentrations of compound in a total volume of $100 \mu \mathrm{L}$. Nine different concentrations $(100 \mu \mathrm{L}-0.4 \mu \mathrm{L})$ were tested, in triplicates. Cisplatin is used as a positive control and wells containing vehicle without compound were used as negative controls. Plates were kept for $48 \mathrm{~h}$ in a $37{ }^{\circ} \mathrm{C}, 5 \%$ $\mathrm{CO}_{2}$ incubator. After incubation, viable cells were detected with the CellTiter 96 AQueous cell proliferation assay (Promega Corp., Madison, WI, USA). Plates were read in a microplate reader (Tecan Infinite ${ }^{\circledR} 200$ PRO series, Mannedorf, Switzerland) at 490nm. Then, dose-response curves were generated and the $\mathrm{IC}_{50}$ values were determined using GraphPad Prism 5.04 software (La Jolla, CA, USA [32].

\section{Conclusions}

The phytochemical investigation of Endiandra kingiana methanolic bark extract has led to the isolation of seven new tetracyclic endiandric acid analogues, named kingianic acids A-G (1-7), together with endiandric acid M (8), tsangibeilin B (9) and compound 10. These compounds were 
screened for Bcl-xL and Mcl-1 binding affinities, and cytotoxic activity on various cancer cell lines. Compound 5 showed moderate cytotoxic activity, with $\mathrm{IC}_{50}$ values in the range $15-17 \mu \mathrm{M}$, and compounds 3, 6 and 9 exhibited weak binding affinity for the anti-apoptotic protein Mcl-1. This is the first report of binding affinity toward Mcl-1 for endiandric acid analogues.

\section{Supplementary Materials}

Supplementary materials: HRESIMS and NMR spectra for compounds 1-7 and 10, and the X-ray crystallographic analysis data of tsangibeilin B (9) and endiandric acid $\mathbf{1 0}$ can be accessed at: http://www.mdpi.com/1420-3049/19/2/1732/s1.

\section{Acknowledgments}

This work was carried out in the frame of an official collaboration agreement between the Centre National de la Recherche Scientifique (France) and the University of Malaya (Kuala Lumpur, Malaysia). We are grateful to Bright Spark Unit, University of Malaya, Malaysia and French Embassy in Malaysia for a scholarship (M.N.A). We thank D. M. Nor, R. Syamsir and T. Leong Eng (UM) for the collection and identification of plant material, and Cheah Foo Kit (UM) for the help with cytotoxic assays. Great appreciation is also given to M. T. Martin (CNRS) and N. Mohamad (UM) for NMR discussion and Y. Six (CNRS) for his careful reading of the manuscript. We thank the University of Malaya (PV050/2012A, RP001-2012B and RP001A-13BIO), the Agence National de la Recherche (ANR), contract number ANR-2010-JCJC-702-1 and ICSN, CNRS for financial support.

\section{Author Contributions}

Mohamad Nurul Azmi and Charlotte Geny contributed equally to this work.

\section{Conflicts of Interest}

The authors declare no competing financial interest.

\section{References}

1. Litaudon, M.; Bousserouel, H.; Awang, K.; Nosjean, O.; Martin, M.-T.; Tran Huu Dau, M.-E.; Hadi, H.A.; Boutin, J.A.; Sévenet, T.; Guéritte, F. A dimeric sesquiterpenoid from a Malaysian Meiogyne as a new inhibitor of Bcl-xL/BakBH3 domain peptide interaction. J. Nat. Prod. 2009, $72,480-483$.

2. Leverrier, A.; Dau, M.E.T.H.; Retailleau, P.; Awang, K.; Guéritte, F.; Litaudon, M. Kingianin A: A new natural pentacyclic compound from Endiandra kingiana. Org. Lett. 2010, 12, 3638-3641.

3. Leverrier, A.; Martin, M.-T.; Servy, C.; Ouazzani, J.; Retailleau, P.; Awang, K.; Mukhtar, M.R.; Guéritte, F.; Litaudon, M. Rearranged diterpenoids from the biotransformation of ent trachyloban-18-oic acid by Rhizopus arrhizus. J. Nat. Prod. 2010, 76, 1121-1125.

4. Leverrier, A.; Awang, K.; Guéritte, F.; Litaudon, M. Pentacyclic polyketides from Endiandra kingiana as inhibitors of the Bcl-xL/Bak interaction. Phytochemistry 2011, 72, 1443-1452. 
5. Ng, F.S.P. Tree Flora of Malaya, a Manual for the Forester; Whitmore, T.C., Ed.; Longman: Kuala Lumpur, Malaysia, 1989; Volume 4, p. 141.

6. Burkill, I.H. A Dictionary of the Economic Products of the Malay Peninsular, 2nd ed.; Government of Malaya and Singapore: Kuala Lumpur, Malaysia, 1966; p. 1773.

7. Maberley, D.J. Mabberley's Plant-Book: A Portable Dictionary of Plants, Their Classification and Uses, 3rd ed.; Cambridge University Press: Cambridge, UK, 2008; p. 1021.

8. Bandaranayake, W.M.; Banfield, J.E.; Black, D.S.C.; Fallon, G.D.; Gatehouse, B.M. Endiandric acid, a novel carboxylic acid from Endiandra introrsa (Lauraceae): X-Ray structure determination. J. Chem. Soc. Chem. Commun. 1980, 162-163, doi:10.1039/C39800000162.

9. Bandaranayake, W.M.; Banfield, J.E.; Black, D.S.C.; Fallon, G.D.; Gatehouse, B.M. Constituents of Endiandra species. I. Endiandric acid, a novel carboxylic acid from Endiandra introrsa (Lauraceae) and a derived lactone. Aust. J. Chem. 1981, 34, 1655-1667.

10. Bandaranayake, W.M.; Banfield, J.E.; Black, D.S.C.; Fallon, G.D.; Gatehouse, B.M. Constituents of Endiandra species. III. 4-[(E,E)-5'-Phenylpenta-2',4'-dien-1'-yl]tetracyclo $\left[5,4,0,0^{2,5}, 0^{3,9}\right]$ undec-10-ene-8-carboxylic acid from Endiandra introrsa (Lauraceae). Aust. J. Chem. 1982, 35, 567-579.

11. Bandaranayake, W.M.; Banfield, J.E.; Black, D.S.C. Constituents of Endiandra species. II. (E)-4-(6'-phenyltetracyclo[5.4.2.03,13.010,12]trideca-4',8'-dien-11'yl)but-2-enoic acid from Endiandra introrsa (Lauraceae) and a derived lactone. Aust. J. Chem. 1982, 35, 557-565.

12. Bandaranayake, W.M.; Banfield, J.E.; Black, D.S.C. Postulated electrocyclic reactions leading to endiandric acid and related natural products. J. Chem. Soc. Chem. Commun. 1980, 902-903, doi:10.1039/C39800000902.

13. Banfield, J.E.; Black, D.S.C.; Fallon, G.D.; Gatehouse, B.M. Constituents of Endiandra species. V. 2-[3',5'-Dioxo-4'-phenyl-10'-\{(E,E)-5"'-phenyl-penta-2",4"'-dien-1"-yl $\}-2$ ',4',6'-triazatetracyclo $\left[5,4,2,0^{2,6}, 0^{8,11}\right]$ tridec12'-en-9'-yl]-acetic acid derived from Endiandra introrsa (Lauraceae). Aust. J. Chem. 1983, 36, 627-632.

14. Banfield, J.E.; Black, D.S.C.; Johns, S.R.; Willing, R.I. Constituents of Endiandra species. IV. 2-(8'-[(E,E)-5"-phenylpenta-2",4"'-dien-1"-yl]bicyclo[4.2.0]octa-2',4'-dien-7'-yl)acetic acid, a biogenetically predicted metabolite of Endiandra introrsa (Lauraceae) and its structure determination by means of 1D and 2D NMR spectroscopy. Aust. J. Chem. 1982, 35, 2247-2256.

15. Nicolaou, K.C.; Petasis, N.A.; Zipkin, R.E. The endiandric acid cascade. Electrocyclizations in organic synthesis. 4. Biomimetic approach to endiandric acids A-G. Total synthesis and thermal studies. J. Am. Chem. Soc. 1982, 104, 5560-5562.

16. Nicolaou, K.C.; Zipkin, R.E.; Petasis, N.A. The endiandric acid cascade. Electrocyclizations in organic synthesis. 3. "Biomimetic" approach to endiandric acids A-G. Synthesis of precursors. J. Am. Chem. Soc. 1982, 104, 5558-5560.

17. Nicolaou, K.C.; Petasis, N.A. Strategies and Tactics in Organic Synthesis; Lindberg, T., Ed.; Academic Press: San Diego, CA, USA, 1984; Volume 1, pp. 155-173.

18. Chouna, J.R.; Nkeng-Efouet, P.A.; Lenta, B.N.; Devkota, K.P.; Neumann, B.; Stammler, H.-G.; Kimbu, S.F.; Sewald, N. Antibacterial endiandric acid derivatives from Beilschmiedia anacardioides. Phytochemistry 2009, 70, 684-688. 
19. Chouna, J.R.; Nkeng-Efouet, P.A.; Lenta, B.N.; Wansi, J.D.; Kimbu, S.F.; Sewald, N. Endiandric acid derivatives from the stem bark of Beilschmiedia anacardioides. Phytochem. Lett. 2010, 3, $13-16$.

20. Talontsi, F.M.; Lamshöft, M.; Bauer, J.O.; Razakarivony, A.A.; Andriamihaja, B.; Strohmann, C.; Spiteller, M. Antibacterial and antiplasmodial constituents of Beilschmiedia cryptocaryoides. J. Nat. Prod. 2013, 76, 97-102.

21. Yang, P.-S.; Cheng, M.-J.; Peng, C.-F.; Chen, J.-J.; Chen, I.-S. Endiandric acid analogues from the roots of Beilschmiedia erythrophloia. J. Nat. Prod. 2009, 72, 53-58.

22. Huang, Y.-T.; Chang, H.-S.; Wang, G.-J.; Cheng, M.-J.; Chen, C.-H.; Yang, Y.-J.; Chen, I.-S. Anti-inflammatory endiandric acid analogues from the roots of Beilschmiedia tsangii. J. Nat. Prod. 2011, 74, 1875-1880.

23. Williams, R.B.; Martin, S.M.; Hu, J.-F.; Norman, V.L.; Goering, M.G.; Loss, S.; O’Neil-Johnson, M.; Eldridge, G.R.; Starks, C.M. Cytotoxic and antibacterial beilschmiedic acids from a gabonese species of Beilschmiedia. J. Nat. Prod. 2012, 75, 1319-1325.

24. Gravel. E.; Poupon, E. Biogenesis and biomimetic chemistry: Can complex natural products be assembled spontaneously? Eur. J. Org. Chem. 2008, 1, 27-42.

25. Huang, Y.-T.; Chang, H.-S.; Wang, G.-J.; Lin, C.-H.; Chen, I.-S. Secondary metabolites from the roots of Beilschmiedia tsangii and their anti-inflammatory activities. Int. J. Mol. Sci. 2012, 13, 16430-16443.

26. Qian, J.; Voorbach, M.J.; Huth, J.R.; Coen, M.L.; Zhang, H.; Ng, S.-C.; Comess, K.M.; Petros, A.M.; Rosenberg, S.H.; Warrior, U.; et al. Discovery of novel inhibitors of Bcl-xL using multiple high-throughput screening platforms. Anal. Biochem. 2004, 328, 131-138.

27. Bruker (2000). SAINT and SMART; Bruker AXS Inc.: Madison, WI, USA, 2000.

28. Sheldrick, G.M. SHELXTL. Version 5.1 Bruker AXS; University of Göttingen: Göttingen, Germany, 2008.

29. Nikolovska-Coleska, Z.; Wang, R.; Fang, X.; Pan, H.; Tomita, Y.; Li, P.; Roller, P.P.; Krajewski, K.; Saito, N.G.; Stuckey, J.A.; et al. Development and optimization of a binding assay for the XIAP BIR3 domain using fluorescence polarization. Anal. Biochem. 2004, 332, 261-273.

30. Cheng, Y.; Prusoff, W.H. Relationship between the inhibition constant (K1) and the concentration of inhibitor which causes 50 per cent inhibition $\left(\mathrm{I}_{50}\right)$ of an enzymatic reaction. Biochem. Pharmacol. 1973, 22, 3099-3108.

31. Zhang, J.H.; Chung, T.D.; Oldenburg, K.R. A simple statistical parameter for use in evaluation and validation of high throughput screening assays. J. Biomol. Screen. 1999, 4, 67-73.

32. Riss, T.L.; Moravec, R.A. Comparison of MTT, XTT, and a novel tetrazolium compound MTS for in vitro proliferation and chemosensitivity assays. Mol. Biol. Cell 1992, 3, 184a-188a.

Sample Availability: Samples of compounds 1-10 are not available.

(C) 2014 by the authors; licensee MDPI, Basel, Switzerland. This article is an open access article distributed under the terms and conditions of the Creative Commons Attribution license (http://creativecommons.org/licenses/by/3.0/). 